\title{
The Effect of Carthamus tenuis Extracts on the Cell Proliferation of Different Tumor Cell Lines
}

\author{
Maissa' Taleb Shawagfeh*
}

\section{Maissa'Taleb Shawagfeh*}

Department of Medical Allied Sciences, Zarqa University College, Al-Balqa Applied University, JORDAN.

\section{Correspondence}

\section{Maissa' Taleb Shawagfeh}

Department of Medical Allied Sciences,

Zarqa University College, Al-Balqa Applied University, JORDAN.

E-mail: mtash48@bau.edu.jo

History

- Submission Date: 01-06-2020;

- Review completed: 25-06-2020.

- Accepted Date: 08-07-2020.

DOI : 10.5530/pj.2020.12.183

Article Available online

http://www.phcogj.com/v12/i6

\section{Copyright}

(C) 2020 Phcogj.Com. This is an openaccess article distributed under the terms of the Creative Commons Attribution 4.0 International license.

\begin{abstract}
Background: Carthamus tenuis is one of the medicinal plants that was used traditionally to treat skin diseases, hemorrhoids, abortion, infertility. It also showed an immunosuppressive role as well as antifungal, antibacterial, anti-inflammatory activity. Although this plant is widespread, there are few studies about its medical applications. Objectives: This study was done to explore the anticancer activity of this plant. Materials and Methods: The aerial parts of the plant were dried, grinded and extracted with hexane, ethyl acetate, and methanol. The extracts were applied in different concentrations to cell cultures of breast (MCF-7), colon (HT-29), prostate (PC-3) and colorectal (CaCo-2) cell lines and fibroblast (MRC5) was used as a control. The anticancer activity was evaluated by 3-(4,5-dimethylthiazol-2yl)-2,5-diphenyltetrazolium (MTT) reduction assay that was measured by spectrophotometer. Results: The results showed that methanol extract significantly $(p<0.05)$ have the highest inhibitory activity on MCF-7, HT-29, PC-3, and CaCo-2 with IC50; $(25.52 \mu \mathrm{g} / \mathrm{ml})$, (17.37 $\mu \mathrm{g} / \mathrm{ml})$, $(25.77 \mu \mathrm{g} / \mathrm{ml}),(24.49 \mu \mathrm{g} / \mathrm{ml})$, respectively. Followed by ethyl acetate extract that moderately inhibit cell growth of PC-3 and CaCo-2 with IC50; $(28.99 \mu \mathrm{g} / \mathrm{ml})$ and $(21.45 \mu \mathrm{g} / \mathrm{ml})$, respectively. n-hexane extract showed no significant inhibitory effect on all cell lines; IC50 (125.52 -152.34 $\mu \mathrm{g} / \mathrm{ml}$ ) when compared to Tamoxifen drug activity as a positive control. Conclusion: Results of this study showed the anticancer activity of the plant extracts in four different kinds of cancers that need further study.
\end{abstract}

Key words: Anticancer, Carthamus tenuis, methanolic extract, IC50, MTT.

\section{INTRODUCTION}

Carthamus genus belongs to the family Asteraceae which includes around 47 species, where 15 of them can be found in the Middle East region and Western Asia. Some of these species had been studied extensively as an important source of an active medicinal compounds. ${ }^{1}$ Carthamus tenuis (Boiss. \& Blanche) Bornm. is one of the species that belongs to this family and although this plant is widespread, few studies took its medicinal uses into consideration. ${ }^{2}$ However, C. tenuis was used traditionally to treat many disorders such as skin diseases, hemorrhoids, abortion and infertility.,4 The plant showed in few studies an anti-bacterial, antifungal, antioxidant and anti-inflammatory activities. ${ }^{4-6}$ It was found that one of its compounds showed an immunesuppresive activity.

Oxidative stress is one of the factors that found to induce different types of cancer, so in many studies, the antioxidant activity for different kinds of plants showed a strong impact on the progression of cancer. ${ }^{8}$ High levels of antioxidants in many plants may inhibit the formation and / or spread of cancer. Thus, as shown by Yang and co-authors, low levels of antioxidants stimulate cell proliferation and prevented by high levels. ${ }^{9}$

Phenolic compounds are generally strong antioxidant. ${ }^{10}$ C. tenuis Boiss. aerial parts were found to contain many compounds with different cellular activities. Majority of these compounds were polyphenolic compounds that show a very strong antioxidant activity. ${ }^{5}$ Caffeic acid, quercetin and luteolin were found to be of the major composition of the total phenolic content in C. tenuis extract, each one of them was found to have an anticancer potential on different cancer cell lines. ${ }^{11}$

The screening of plant extracts has been of great interest to scientists in the search for new drugs for effective treatment of several diseases. ${ }^{12,13}$ Cancer is one of the most dangerous diseases in humans and presently there is considerable scientific discovery of new anticancer agents from natural products. ${ }^{14}$ Plant derived natural products have received considerable attention in recent years, due to their diverse pharmacological properties including cytotoxic and cancer chemo preventive effects. ${ }^{15}$

So, because the plant showed some medicinal and biological activity and appeared in few researches, the present work was conducted in order to study the antiproliferative and anticancer activity of different extracts of $C$. tenuis plant on different cancer cell lines and to give an insight about the medical importance of this plant.

\section{MATERIAL AND METHODS}

\section{Plant material}

The plant was collected from the north area of Jordan from the village called (Izmal) at Al- Koura District/ Irbid Governorate, and was taxonomically identified 
and authenticated at National Virtual Herbarium by Dr Dawud AlEisawi under the specimen ID\# NVH20150025. ${ }^{16-33}$

\section{Chemicals}

All chemicals used were purchased through local companies for scientific supplies. Absolute Methanol, Ethyl acetate, n-hexane, MTT (3-(4,5-dimethylthiazol-2yl)-5-(3-carboxymethoxyphenyl)-2-(4sulfophenyl)-2H-tetrazolium) solution, penicillin and streptomycin antibiotics from (Sigma-Aldrich, St. Louis, MO, USA). DMEM (Dulbecco's modified Eagle's Medium), RPIM-1640 (Roswell Park Memorial Institute Medium), and fetal bovine serum (FBS) from (Gibco BRL, Grand Island, NY, USA). dimethyl sulfoxide (DMSO), Trypsin and EDTA from (Promega Corp., WI, USA).

\section{Plant extract preparation}

Plant extract was prepared according to Do et al., 2014 with some minor modifications. ${ }^{17}$ The plant aerial parts were air dried, grounded, and 500 grams of the grind was soaked in $1000 \mathrm{ml}$ of different solvents for 1 week at $60^{\circ} \mathrm{C}$ for each. The solvents that were used in this study are (Methanol, $n$-hexane, ethyl acetate). The extracts were then filtered using filter paper and evaporated under vacuum for solvents removal by using rotary evaporator (model Lare-A20) at $50^{\circ} \mathrm{C}$ and were stored at $-20^{\circ} \mathrm{C}$ for further use.

A stock concentration of each extract was prepared by dissolving $5 \mathrm{mg}$ in $50 \mu \mathrm{l}$ DMSO and was then diluted with culture medium (RPMI1640 ) to be used for cell proliferation assessment.

\section{Cell lines preparations}

Colon cancer cell line (HT29), Prostate cancer cell line (PC-3), breast cancer cell line (MCF-7), colorectal cell line (CaCo-2) used in this study were cultured in the RPMI-1640 medium with $10 \%$ fetal bovine serum. Fibroblast cell line (MRC-5) was kept in DMEM supplemented with $10 \%$ FBS as a normal cell line control. Penicillin and streptomycin antibiotics were added to all formal culture media, and cell lines were cultured at $37^{\circ} \mathrm{C}$ in $5 \% \mathrm{CO} 2$ incubator. When cells became $80 \%$ confluent, RPMI1640 media without FBS was added and they were harvested using (0.025\% trypsin and $0.02 \%$ EDTA) by centrifugation. Then cells were taken and seeded in 96 well culture plate at a concentration of $\left(1 \times 10^{4}\right.$ cells/ well) in RPMI-1640 media for extract application.

\section{Assessment of cell proliferation}

Cell proliferation was determined by (MTT) assay according to Mosmann, $1983 .{ }^{18}$ Different concentrations for each plant extract (20, $40,80,160,320 \mu \mathrm{g} / \mathrm{ml}$ ) were prepared using RPMI- 1640 medium and added to each cell line in microtiter plate wells (cancerous and normal cell lines). Plates then were incubated at $37^{\circ} \mathrm{C}$ with $5 \% \mathrm{CO}_{2}$ for $72 \mathrm{~h}$.

The blank of the test was cells with no treatment as negative control and Tamoxifen drug $(20 \mu \mathrm{g} / \mathrm{ml})$ was used as a positive control treatment. After incubation for $72 \mathrm{~h}$ at $37^{\circ} \mathrm{C}$ in $\mathrm{CO}_{2}$ incubator, MTT was added at concentration $(0.5 \mathrm{mg} / \mathrm{ml})$ incubated for 4 hours at $37^{\circ} \mathrm{C}$. The optical density for each well was measured spectrophotometrically at wavelength $570 \mathrm{~nm}$ using ELISA reader. Values were set as the mean \pm SE of three assays for each treatment and the significance of differences was set at value of $\mathrm{p}<0.05$ compared to the nontreated cells.

Cell viability in MTT assays was calculated as a percentage of treated to untreated cells (control value) by the following equation:

$\%$ Cell Viability $=$ OD of treated cells / OD of untreated cells (control) $\times 100 \%$

The growth inhibitory effect of the extracts was used to express the anticancer activity of the plant and it was calculated by the following equation:
Growth Inhibition $\%=100-\%$ Cell Viability

The growth inhibitory concentration (IC50) will be used to express the anticancer activity of the samples. IC50 for the tested extracts was calculated using the equation of trend line equation of a scatter plot in MS- Excel.

\section{Statistics}

Data were analyzed using SPSS 12.0 software for Windows. The experimental data were expressed as mean $\pm \mathrm{SD}$, the significance of difference among the various treated groups and control groups was analyzed and the level of significance was set at $\mathrm{p}<0.05$.

\section{RESULTS}

Regarding to the antiproliferative activities of Carthamus tenuis three extracts (methanol, ethyl acetate and n-hexane) presented a dosedependent response in all cancerous cell lines as shown in figures 1-4. The cytotoxicity of $C$. tenuis extracts against human cancer cell lines indicated that the extracts showed different growth inhibitory activity on breast MCF-7, colon HT-29, prostate PC-3, and colorectal CaCo-2 compared to the normal cell line fibroblast (MRC-5).

Results showed that the inhibitory effect on cell growth for methanol and ethyl acetate extracts is high, while it was low for n-hexane extract compared to Tamoxifen as a positive control drug. These resulted effects for the three extracts were significant when compared to the extract's negative effect on fibroblast cell line (Figure 5).

Figure 1 shows the cytotoxicity results with extract numbers corresponding to those in Table 1. Cisplatin caused $48.5 \pm 2.41$, $78.0 \pm 0.61$ and $72.0 \pm 1.47,82.0 \pm 1.31(\mathrm{SD}, \mathrm{n}=4)$ at 10 and $100 \mu \mathrm{M}$ inhibition for MCF-7 and HT29 respectively. In the MCF-7 cell line, Sapium had comparable activity to the positive control Cisplatin for all the concentrations tested. Figure 1 shows the cytotoxicity results with extract numbers corresponding to those in Table 1. Cisplatin caused $48.5 \pm 2.41,78.0 \pm 0.61$ and $72.0 \pm 1.47,82.0 \pm 1.31(S D, n=4)$ at 10 and $100 \mu \mathrm{M}$ inhibition for MCF-7 and HT29 respectively. In the MCF-7 cell line, Sapium had comparable activity to the positive control Cisplatin for all the concentrations tested. Figure 1 shows the cytotoxicity results with extract numbers corresponding to those in Table 1. Cisplatin caused $48.5 \pm 2.41,78.0 \pm 0.61$ and $72.0 \pm 1.47,82.0$ $\pm 1.31(\mathrm{SD}, \mathrm{n}=4)$ at 10 and $100 \mu \mathrm{M}$ inhibition for MCF-7 and HT29 respectively. In the MCF-7 cell line, Sapium had comparable activity to the positive control Cisplatin for all the concentrations tested. Figure 1 shows the cytotoxicity results with extract numbers corresponding to those in Table 1. Cisplatin caused $48.5 \pm 2.41,78.0 \pm 0.61$ and 72.0 $\pm 1.47,82.0$

$\pm 1.31(\mathrm{SD}, \mathrm{n}=4)$ at 10 and $100 \mu \mathrm{M}$ inhibition for MCF-7 and HT29 respectively. In the MCF-7 cell line, Sapium

had comparable activity to the positive control Cisplatin for all the concentrations tested.

For MCF-7 cell line, C. tenuis extracts caused (64\%), (65\%), (33\%) inhibition activity at $40 \mu \mathrm{g} / \mathrm{ml}$ and $(88 \%),(83 \%),(66 \%)$ inhibition

Table 1: IC50 values of methanol, ethyl acetate, $\mathbf{n}$-hexane, and Tamoxifen on the four tested cell lines.

\begin{tabular}{ccccc}
\hline \multirow{2}{*}{ Cell line } & \multicolumn{4}{c}{ IC50 $(\mu \mathrm{g} / \mathrm{ml})$} \\
& Methanol & Ethyl acetate & $\mathrm{n}$-Hexane & Tamoxifen \\
\hline MCF-7 & 25.52 & 35.02 & 152.34 & 14.65 \\
HT-29 & 17.37 & 31.32 & 125.52 & 6.27 \\
PC-3 & 25.77 & 28.99 & 135.18 & 16.36 \\
CaCo-2 & 24.49 & 21.45 & 126.6 & 13.51 \\
MCR-5 & 771.06 & 754.3 & 828.37 & 32.51 \\
\hline
\end{tabular}


activity at $160 \mu \mathrm{g} / \mathrm{ml}$ for methanol, ethyl acetate, and n-hexane extracts, respectively, as shown in Figure 1.

For HT-29 cell line, C. tenuis extracts caused (55\%), (49\%), (36\%) inhibition activity at $40 \mu \mathrm{g} / \mathrm{ml}$ and $(83 \%),(80 \%),(68 \%)$ inhibition activity at $160 \mu \mathrm{g} / \mathrm{ml}$ for methanol, ethyl acetate, and $\mathrm{n}$-hexane extracts, respectively, as shown in Figure 2.

For PC-3 cell line, C. tenuis extracts caused (51\%), (47\%), (41\%) inhibition activity at $40 \mu \mathrm{g} / \mathrm{ml}$ and (84\%), (81\%), (55\%) inhibition activity at $160 \mu \mathrm{g} / \mathrm{ml}$ for methanol, ethyl acetate, and n-hexane extracts, respectively, as shown in Figure 3.

For CaCo-2 cell line, C. tenuis extracts caused (52\%), (59\%), (36\%) inhibition activity at $40 \mu \mathrm{g} / \mathrm{ml}$ and $(80 \%),(86 \%),(61 \%)$ inhibition activity at $160 \mu \mathrm{g} / \mathrm{ml}$ for methanol, ethyl acetate, and n-hexane extracts, respectively, as shown in Figure 4.

For MCR-5 cell line, C. tenuis extracts caused (15\%), (11\%), (5\%) inhibition activity at $40 \mu \mathrm{g} / \mathrm{ml}$ and (22\%), (25\%), (20\%) inhibition activity at $160 \mu \mathrm{g} / \mathrm{ml}$ for methanol, ethyl acetate, and n-hexane extracts, respectively, as shown in Figure 5.

In Figure 5, The three extracts along with Tamoxifen as a positive control were applied to MCR- 5 cell line and used as negative control for cytotoxicity measurements. The results show the low percent of cell growth inhibition of the cells for all extracts compared to the growth inhibition percent shown by Tamoxifen as positive control.

As shown in Table 1, the highest inhibition on cell proliferation was observed with methanolic extracts that showed IC50 values between (17.37- $25.77 \mu \mathrm{g} / \mathrm{ml}$ ) on all cancer cell lines, followed by ethyl acetate extracts that showed a moderate inhibition activity with IC50 values between $(21.45-35.02 \mu \mathrm{g} / \mathrm{ml})$. For $\mathrm{n}$-hexane extract, it showed a very low antiproliferative activity where its IC50 was between (125.52 $-152.34 \mu \mathrm{g} / \mathrm{ml}$ ) compared to its effect on MCR-5 normal cell line IC50 $(828.37 \mu \mathrm{g} / \mathrm{ml})$.

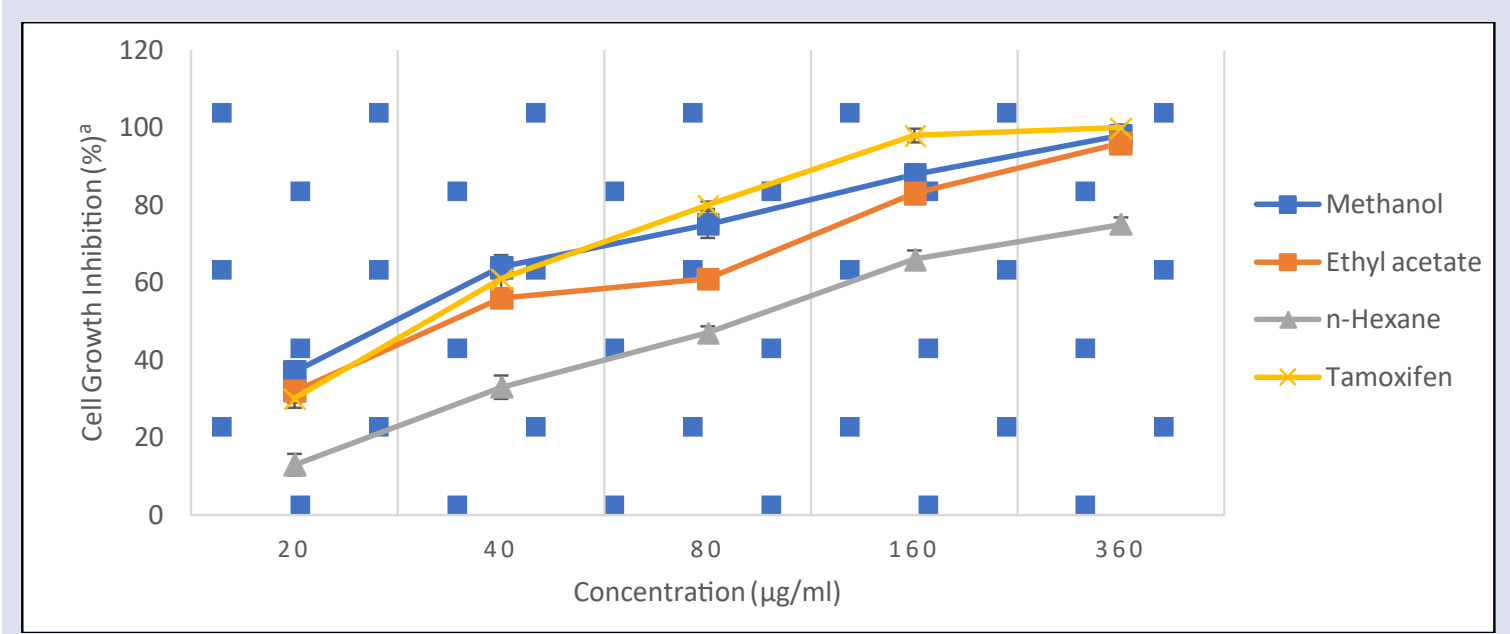

Figure 1: Anticancer activity of different $C$. tenuis extracts applied to MCF-7 cell line ( $\diamond$ Methanol, $\square$ Ethyl acetate, $\Delta$ n-Hexane) and * Tamoxifen as a positive control drug. Data are expressed as mean $\pm S D(n=3, P<0.05$. No significant differences were found between the extracts compared to non- treated cells).

${ }^{a}$ DMSO and culture media in each experiment was used as control and resulted in $0 \%$ inhibition.

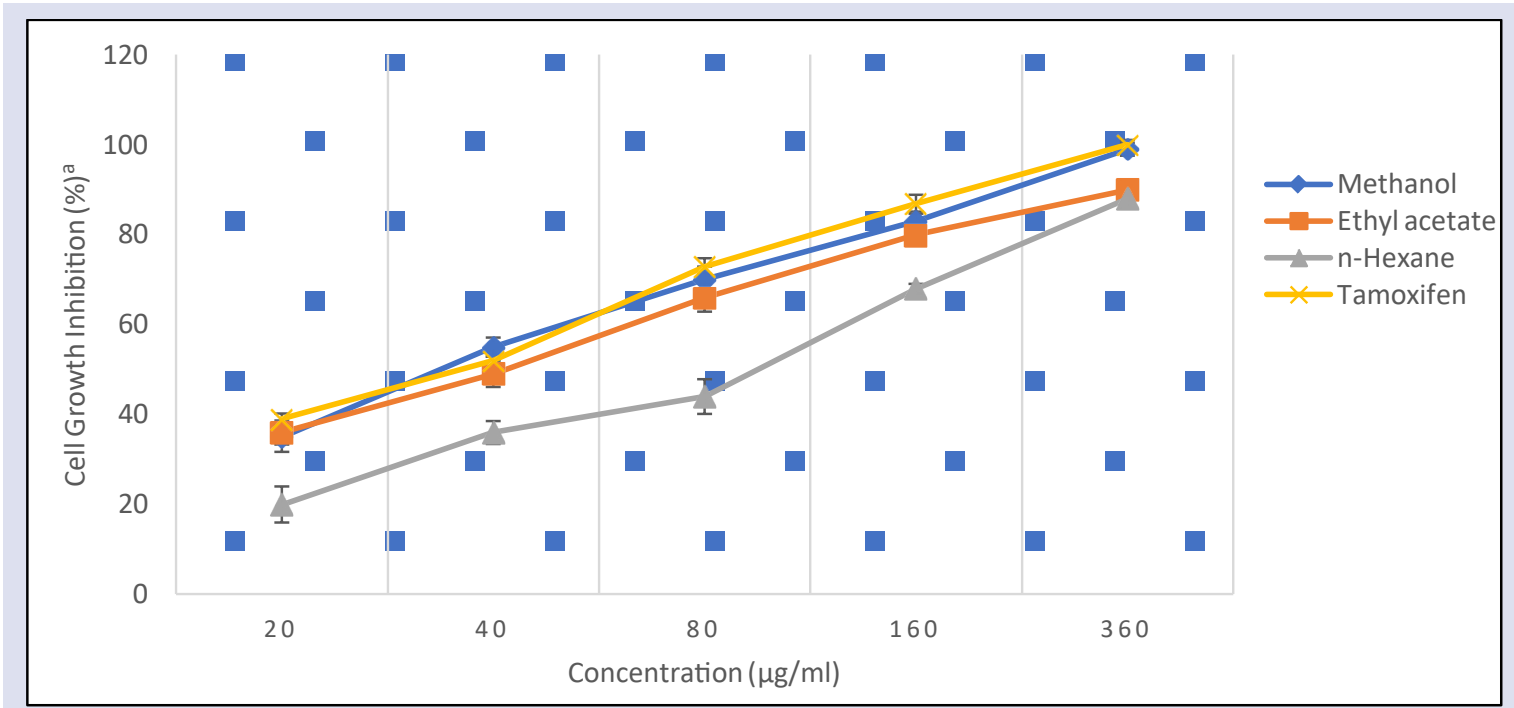

Figure 2: Anticancer activity of different $C$. tenuis extracts applied to HT-29 cell line ( $\diamond$ Methanol, $\square$ Ethyl acetate, $\Delta \mathrm{n}$-Hexane) and * Tamoxifen as a positive control drug. Data are expressed as mean \pm SD ( $n=3, P<0.05$. No significant differences were found between the extracts compared to non- treated cells).

DMSO and culture media in each experiment was used as control and resulted in $0 \%$ inhibition. 


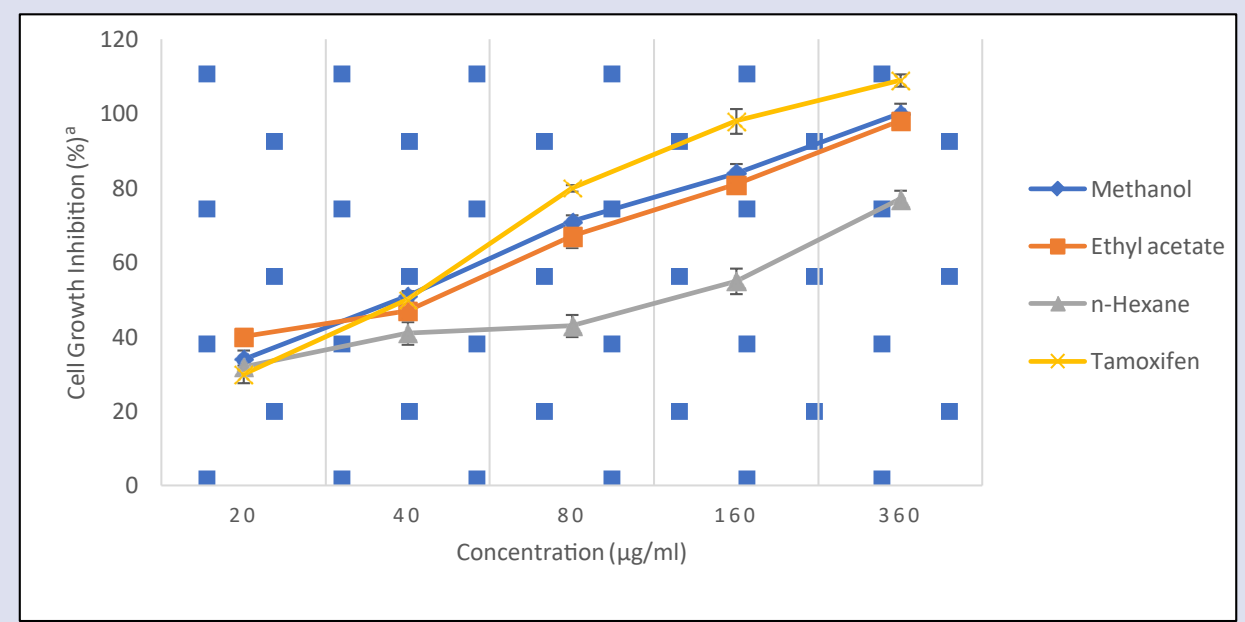

Figure 3: Anticancer activity of different $C$. tenuis extracts applied to PC-3 cell line $(\diamond$ Methanol, $\square$ Ethyl acetate, $\Delta n$-Hexane) and ${ }^{*}$ Tamoxifen as a positive control drug. Data are expressed as mean $\pm S D(n=3, P<$ 0.05 . No significant differences were found between the extracts compared to non- treated cells).

a DMSO and culture media in each experiment was used as control and resulted in $0 \%$ inhibition.

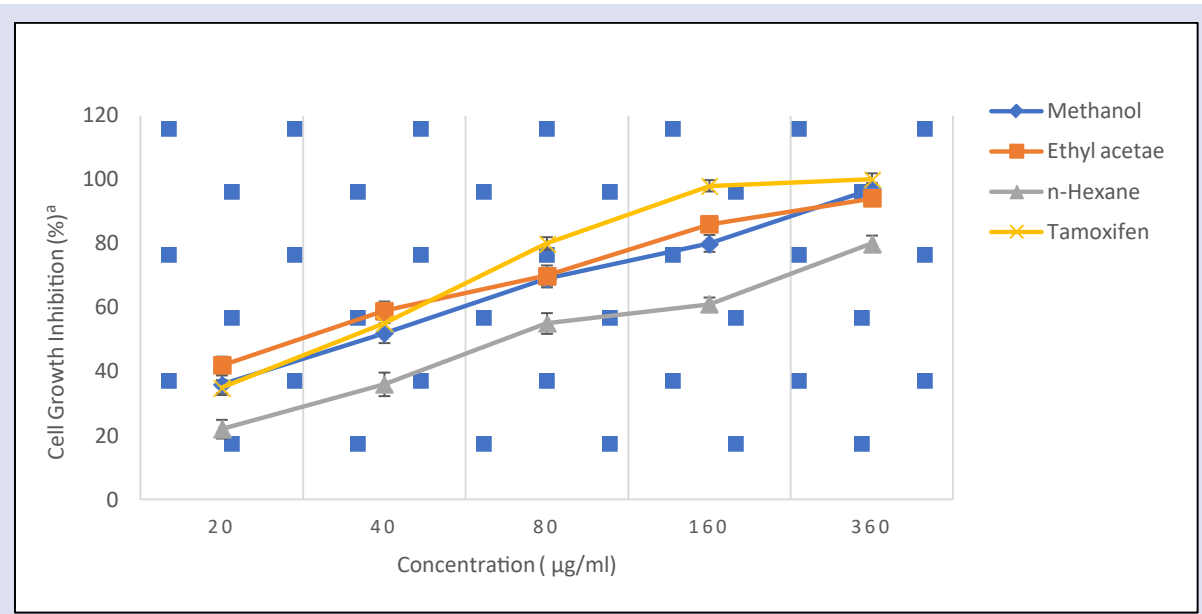

Figure 4: Anticancer activity of different $C$. tenuis extracts applied to CaCo-2 cell line ( $\diamond$ Methanol, $\square$ Ethy acetate, $\Delta \mathrm{n}$-Hexane) and ${ }^{*}$ Tamoxifen as a positive control drug. Data are expressed as mean $\pm S D(n=3$, $\mathrm{P}<0.05$. No significant differences were found between the extracts compared to non- treated cells). a DMSO and culture media in each experiment was used as control and resulted in $0 \%$ inhibition.

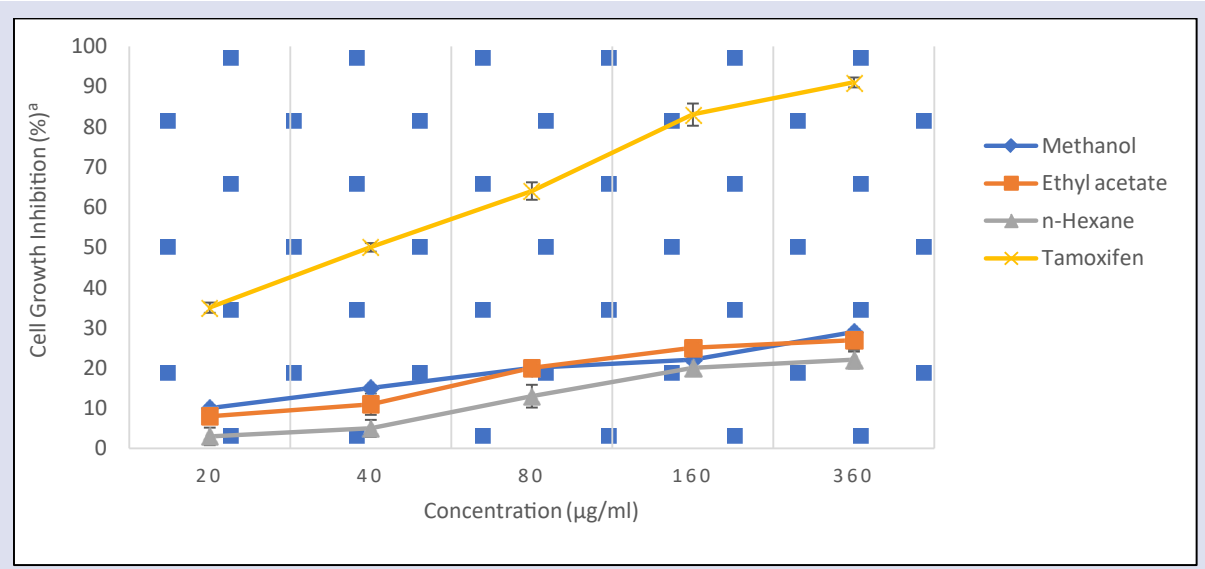

Figure 5: Anticancer activity of different $C$. tenuis extracts applied to MCR-5 cell line $(\diamond$ Methanol, $\square$ Ethyl acetate, $\Delta \mathrm{n}$-Hexane) and ${ }^{*}$ Tamoxifen as a positive control drug. Data are expressed as mean $\pm S D(n=3$, $P<0.05$. No significant differences were found between the extracts compared to non- treated cells). ${ }^{a}$ DMSO and culture media in each experiment was used as control and resulted in $0 \%$ inhibition. 


\section{DISCUSSION}

Carthamus tenuis studies were limited although of its biological and medicinal activities and its use in traditional medicine to treat some disorders. So, this study was done to explore the anticancer activity of this plant extract on different cancer cell lines in vitro.

The results showed that methanolic extract showed a significant high inhibition activity on all cancer cell lines used in this study followed by ethyl acetate extract and then $n$-hexane extract. The American National Cancer Institute (NCI) guidelines set the limit of activity for crude extracts at $50 \%$ inhibition (IC50) of proliferation of less than $30 \mu \mathrm{g} / \mathrm{mL}$ after the exposure time of 72 hours. ${ }^{19}$ The results of the present study showed potent cytotoxic effects on MCF-7, HT-29, PC-3, and CaCo-2 cells with $C$. tenuis extracts. The IC50 value was found for methanolic extract $(25.52,17.37,25.77,24.49 \mu \mathrm{g} / \mathrm{ml})$ and ethyl acetate extract $(28.99,21.45 \mu \mathrm{g} / \mathrm{ml})$ at different cell lines to be lower than that specified by NCI, USA for categorization of plant extract as anticancer agent.

Ethyl acetate extract significantly $(\mathrm{P}<0.05)$ showed a high inhibitory activity on PC-3 and CaCo- 2 cell lines but a moderate inhibition activity on MCF-7 and HT-29 cell lines. These findings indicate that C. tenuis extracts (methanol and ethyl acetate) contain compounds that may confer antiproliferative activity. Although n-hexane extract showed a very low anticancer activity compared to the other polar extracts (methanol and ethyl acetate), its effect on cells was significant when compared with its effect on normal cell line (MCR-5). This indicates that further purification and isolation should be done for the components of this extract that have the active antiproliferative effect on cancerous cells.

The growth inhibition potency for $C$. tenuis extracts may due to its phytochemical composition that had been studied by El-Hela et. al. ${ }^{11}$ They found that the total phenolic content in C. tenuis was $65.8 \mathrm{mg}$ gallic acid equivalent (GAE) /g dry weight in methanolic extract in which different compounds have been identified and isolated. These compounds were; Caffeic-o-9- acid, quercetin, luteolin, 3'-methoxy luteolin, proline, and choline. ${ }^{11}$

In Abarca-Vargas et al. study the maximum total phenolic content amount and highest antioxidant potential were obtained when extraction was made by methanol. ${ }^{19}$ In other study, a linear correlation was found between antioxidant activity and total phenolic content for aqueous and methanolic extracts. ${ }^{21}$ This may explain the higher anticancer activity in methanolic extract compared to ethyl acetate and n-hexane extracts used in this study.

Caffeic acid was reported to have antiproliferative activity against different cancer cell lines such as breast cancer, hepatocarcinoma, and cervical cancer. ${ }^{22-24}$ The anticancer properties of caffeic acid was found to be associated with its antioxidant and pro-oxidant capacity mediated oxidative DNA damage and its downstream signaling induces apoptotic cancer cell death. In other hand, quercetin has also antioxidant properties, where it has anticancer properties by arresting the cell cycle and induce apoptosis. ${ }^{25}$ Quercetin showed anticancer activity on different kinds of cancer; breast, prostate, liver, bladder and colon. ${ }^{26-30}$ Beside all these documented results, luteolin has been found to have a variety of beneficial properties including those as an anti-inflammatory and anticancer agent by modulating cellular signaling pathways. ${ }^{31,32}$

The presence of these active compounds in C. tenuis that have a wide antiproliferative effects and strong antioxidant activity, may explain its anticancer potential on different cell lines used in this study.

\section{CONCLUSION}

In conclusion, the present study provides a preliminary results about the cytotoxicity of $C$. tenuis extracts against different human cancer cell lines indicating further research is to be carried out to fractionate and purify the plant extract, in order to find out the molecules responsible for the antiproliferation activity observed.

\section{ACKNOWLEDGEMENTS}

This study was supported by Al-Balqa Applied University/ Al-Salt/ Jordan and performed in the laboratories of Zarka University College. The author is thankful to Dr Rana Abu Al-Dahab at Jordan University for gifting cell lines that had been used to complete this study.

\section{REFERENCES}

1. Mansoor Ahmad, Imran Waheed, Muhammad Khalil-ur-Rehman, Uzma Niaz, Syed Saeed-ul-Hassan. A review on Carthamus oxycanth. Pak J Pharm. 20072010;20-23(1 \& 2):37-41.

2. Vilatersana R, Garnatje T, Susanna A, Garcia-Jacas N. Taxonomic problems in Carthamus (Asteraceae): RAPD markers and sectional classification. Bot $J$ Linean Soc. 2005;147:375-83

3. Baydoun S, Chalak L, Dalleh H, Arnold N. Ethnopharmacological survey of medicinal plants used in traditional medicine by the communities of Mount Hermon, Lebanon. J Ethnopharmacol. 2015;173:139-56.

4. Kuete V, Wiench B, Hegazy ME, Mohamed TA, Fankam AG, Shahat AA, Efferth T. Antibacterial Activity and Cytotoxicity of Selected Egyptian Medicinal Plants. Planta Med. 2012;78:193-9.

5. Azab A. Total phenolic content, antioxidant capacity and antifungal activity of extracts of Carthamus tenuis and Cephalaria joppensis. European Chemical Bulletin. 2018;(7):156-61.

6. Azab A. Antioxidant and Anti-Inflammatory Activities of Plants Extracts of Israel and Palestine. Unexplored Paradise. European Chemical Bulletin. 2019;8(8):244-56

7. Ibrahim T, El-Hela AA, Al-Massarani $\mathrm{S}$, Abo-Elfetoh NM, Abdallah GM Immunosuppressive Principles from Carthamus tenuis Growing in Egypt. Indian Journal of Natural Sciences. 2017;(41):12130-7.

8. Brown NS, Bicknell R. Hypoxia and oxidative stress in breast cancer. Oxidative stress: its effects on the growth, metastatic potential and response to therapy of breast cancer. Breast Cancer Research. 2001;3(5):323-27.

9. Yang GY, Wang ZY, Kim S, Liao J, Seril DN, Chen X, et al. Characterization of early pulmonary hyperproliferation, tumor progression and inhibition by black tea in a 4- (methylnitrosamino)-1-(3-pyridyl)-1-butanone (NNK)-induced lung tumorigenesis model with A/J mice. Cancer Res. 1997;57(10):1889-94.

10. Rice-Evans C, Miller N, Paganga G. Antioxidant properties of phenolic compound. Trends Plant Sci. 1997;2(4):152-9.

11. El-Hela A, Ibrahim T, Abdel-Hady N, Al-Massarani S, Abd-Allah G. Phytochemical and Biological Investigation of Carthamus tenuis Boiss. growing in Egypt. Planta Med. 2013;79-PN46.

12. Dimayuga RE, Garcia Sk. Antimicrobial screening of medicinal plants from Baja California sur, Mexico, J Ethnopharmacol. 1991;31:181-92.

13. Bulter MS. The role of natural product chemistry in drug discovery. J Nat Prod. 2004;67:2141-53.

14. Nweman DJ, Cragg GM, Sander KM. The influence of natural products upon drug discovery. Nat Prod Rep. 2000;17:215.

15. Thakkar KN, Prasad AK, Nayak J, lyer SI, Kumar S. Antioxidant and in vitro cytotoxic activity of extracts of aerial parts of Cocculus hirsutus (L) using cell line cultures (breast cell line). The Journal of Phytopharmacology. 2014;3(6):395-99.

16. Al-Eisawi DM. Field Guide to Wildflowers of Jordan and Neighboring Countries. 1998, National Library/Jordan Press Foundation "AlRai", Amman, Jordan.

17. Do QD, Angkawijaya AE, Tran-Nguyen PL. Effect of extraction solvent on total phenol content total flavonoid content, and antioxidant activity of Limnophilaaromatica, Journal of Food and Drug Analysis. 2014;22(3):296302

18. MosmannT. Rapid colorimetric assay for cellular growth and survival: application to proliferation and cytotoxicity assays. J Immunol Methods. 1983;65(1-2):5563.

19. Suffness M, Pezzuto JM. Assays related to cancer drug discovery. In: Hostettmann K, ed. Methods in plant biochemistry: assays for bioactivity. London: Academic; 1990. p.71-133.

20. Abarca-Vargas R, Peña Malacara C, Petricevich V. Characterization of Chemical Compounds with Antioxidant and Cytotoxic Activities in Bougainvillea $\mathrm{x}$ buttiana Holttum and Standl, (var. Rose) Extracts. Antioxidants. 2016;5(4):45.

21. Alali F, Tawaha K El-ElimatT, Syouf M, El-Fayad M, Abulaila K. Antioxidant activity and total phenolic content of aqueous and methanolic extracts of Jordanian plants: an ICBG project. Natural Product Research. 2007;21(12):1121-31. 
22. Seresht $H$, Cheshomi $H$, Falanji F, Motlagh F, Hashemian M, Mireskandari $E$. Cytotoxic activity of caffeic acid and gallic acid against MCF-7 human breast cancer cells: An in silico and in vitro study. Avicenna J Phytomed. 2019;9(6):574-86.

23. Espíndola KM, Ferreira RG, Narvaez LE, Rosario AC, da Silva AH, Silva $A$, et al. Chemical and Pharmacological Aspects of Caffeic Acid and Its Activity in Hepatocarcinoma. Front Oncol. 2019;9:541.

24. Changa WC, Hsieh CH, Hsiao MW, Line WC, Hunga YC, Ye CJ. Caffeic Acid Induces Apoptosis in Human Cervical Cancer Cells Through the Mitochondria Pathway. Taiwanese Journal of Obstetrics and Gynecology. 2010;49(4):419-24.

25. Hashemzaei M, Delarami Far A, Yari A, Heravi R, Tabrizian K, Taghdisi S, et al. Anticancer and Apoptosis inducing Effects of Quercetin in Vitro and in Vivo. Oncology Reports. 2017;38(2):819-28.

26. Deng XH, Song HY, Zhou YF, Yuan GY, Zheng FJ. Effects of Quercetin on the Proliferation of Breast Cancer Cells and Expression of Survivin in vitro. Exp Ther Med. 2013;6(5):1155-8

27. Yang $F$, Song $L$, Wang $H$, Wang $J, X u Z$, Xing $N$. Quercetin in prostate cancer: Chemotherapeutic and chemo preventive effects, mechanisms and clinical application potential (Review). Oncology Reports. 2015;33:2659-68.
28. Zhou J, Fang L, Liao J, Li L, Yao W, Xiong Z, Zhou X. Investigation of the AntiCancer Effect of Quercetin on HepG2 Cells in Vivo. PLo S One. 2017;12(3).

29. Su Q, Peng M, Zhang Y, Xu W, Darko K, Tao T, et al. Quercetin Induces Bladder Cancer Cells Apoptosis by Activation of AMPK Signaling Pathway. Am J Cancer Res. 2016:6(2):498-508.

30. Rosa LS, Silva NJ, Soares NC, Monteiro MC, Teodoro AJ. Anticancer Properties of Phenolic Acids in Colon Cancer - A Review. J Nutr Food Sci. 2016;6:2.

31. Lin Y, Shi R, Wang X, Shen H-M. Luteolin, a flavonoid with potentials for cancer prevention and therapy. Curr Cancer Drug Targets. 2008;8(7):634-46.

32. Ju W, Wang $X$, Shi $H$, Chen W, Belinsky SA, Lin Y. A critical role of luteolininduced reactive oxygen species in blockage of tumor necrosis factor-activated nuclear factor-kappa B pathway and sensitization of apoptosis in lung cancer cells. Mol Pharmacol. 2007:71:1381-8.

33. Web site: Royal botanic garden organization, [http://royalbotanicgarden.org], National Virtual Herbarium, 2011-2012, Royal Botanic Garden, Jordan. 


\section{GRAPHICAL ABSTRACT}

Carthamus tenuis

1. Drying

2. Grinding

3. Soaking

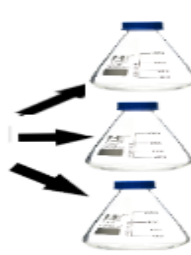

Methanol

Ethyl acetate

n-Hexane

\section{Evaporation}

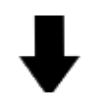

Extracts

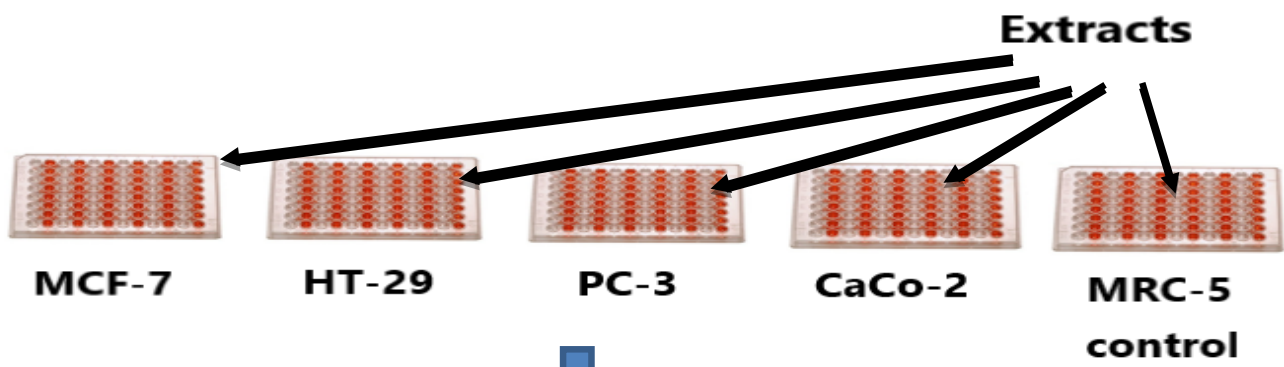

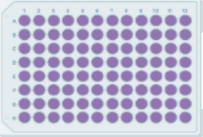

MTT Reduction

Assay
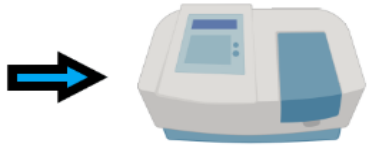

Spectrophotometer

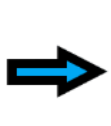

\section{Cell}

Cell Growth Inhibition(\%)

\&

IC50 Calculations

for each extract on the

four different cell lines

different $C$. tenuis extracts applied to MCF-7 cell line

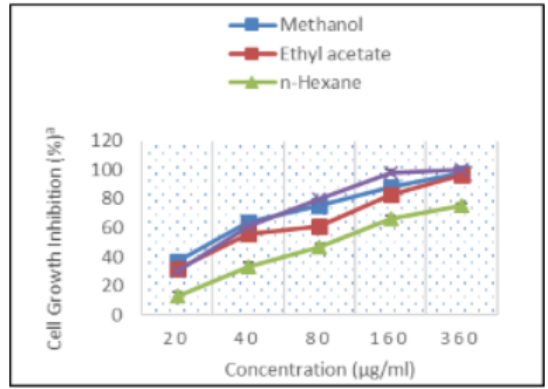

\begin{tabular}{|l|c|c|c|c|}
\hline \multirow{2}{*}{ Cell line } & \multicolumn{4}{|c|}{ IC50 $(\mu \mathrm{g} / \mathrm{ml})$} \\
\cline { 2 - 5 } & Methanol & $\begin{array}{c}\text { Ethyl } \\
\text { acetate }\end{array}$ & $\mathbf{n}$-Hexane & Tamoxifen \\
\hline MCF-7 & 25.52 & 35.02 & 152.34 & 14.65 \\
\hline HT-29 & 17.37 & 31.32 & 125.52 & 6.27 \\
\hline PC-3 & 25.77 & 28.99 & 135.18 & 16.36 \\
\hline CaC0-2 & 24.49 & 21.45 & 126.6 & 13.51 \\
\hline MCR-5 & 771.06 & 754.3 & 828.37 & 32.51 \\
\hline
\end{tabular}




\section{ABOUT AUTHORS}

\section{MAISSA' TALEB AHMAD SHAWAGFEH}

Biological Sciences, Associate Professor, Biology, Biotechnology and Genetic Engineering, Al-Balqa' Applied University, Zarka University College/ Zarqa-JORDAN.

Dr Maissa' joined the academic staff of Al Balqa University in the Department of Allied Medical Sciences and was promoted to the rank of Associate Professor in 2016.

During her academic career Dr Maissa' had taught many under graduate and graduate courses and assumed many administrative positions as the head of the Department of Allied Medical and the vice dean of Zarqa University College together with memberships in many committees related to teaching, examination, students' affairs, programs accreditations and many others.

She had developed many skills during her career in many disciplines by attending hands on courses and inhouse training and provided many volunteered community services.

She has many publications in well-known international Journals. She has interests in many fields concerned with expression and production of recombinant proteins on a large scale, antioxidants, pharmaceutics, and stem cell biotechnology.

Cite this article: Shawagfeh MT. The Effect of Carthamus tenuis Extracts on the Cell Proliferation of Different Tumor Cell Lines. Pharmacogn J. 2020;12(6):1332-9. 